\title{
RESPONSE OF RICE PRODUCTIVITY TO MINERAL AND ORGANIC FERTILIZERS UNDER TWO PLANTING METHODS Ahmed, A. A. ${ }^{1}$ and M. E. Meleha ${ }^{2}$ \\ ${ }^{1}$ Agronomy Dept., Fac. of Agric., Kafrelsheikh Univ., Egypt. \\ 2 Water Management Res. Inst., National Water Res. Centre, Cairo, Egypt.
}

\begin{abstract}
Two field experiments were conducted at the Experimental Farm of Water Requirements Research Station, Kafrelsheikh Governorate, North Delta, Water Management Research Institute, National Water Research Centre, Egypt,during 2010 and 2011 seasons, to study the effect of mineral and organic nitrogen fertilizers on rice productivity under traditional transplanting and transplanting in bottom of beds methods and so on water saving and its use effeciency under the conditions of Kafrelsheikh Governorate for rice cultivar Sakha 105. Fertilizer treatments were as following (160 kg N/ha, $120 \mathrm{~kg} \mathrm{~N} /+5$ tons compost/ ha and $80 \mathrm{~kg} \mathrm{~N}+5$ tons compost/ ha). Treatments were arranged in split plot design with four replicates. The main plots included the two planting methods, while, the three fertilizer treatments were allocated at the sub plots. The obtained results could be summarized as follows:

The results reveal that the method of planting in bottom of beds led to significantly increased in dry weight at heading, 1000 grain weight, grain yield and harvest index in both seasons as well as number of grains/panicle in the second season compared with the method of traditional transplanting, which recorded a highly significant values in plant height, number of panicles/hill in both seasons and straw yield in the second season.

Data show that planting in bottom of beds led to significant increase in water use efficiency and achieved water saving of 4798 and $4788 \mathrm{~m}^{3} / \mathrm{ha}$ ( 2016 and 2012 $\mathrm{m}^{3 / \mathrm{fed}}$.) in the first and second seasons, respectively as compared with traditional transplanting method.

The obtained results show that application of mineral nitrogen $120 \mathrm{~kg} \mathrm{~N}$ in combined with 5 tons compost/ha significantly recorded the highest values of plant height number of panicles/hill, number of grains/panicle, 1000 grain weight, grain and straw yields and harvest index in both seasons as well as dry weight only in the first season

The treatment of $160 \mathrm{~kg} \mathrm{~N} / \mathrm{ha}$ didn't significantly differed with the treatment of $120 \mathrm{~kg} \mathrm{~N}+5$ tons compost/ha in 1000 grain weight in the first season, grain yield in the second season and harvest index in both seasons.

From the obtained results under these conditions of this study, it could be concluded that planting rice in bottom of beds saved water in average of $4793 \mathrm{~m}^{3} / \mathrm{ha}$ and increased water use efficiency as compared with traditional transplanting. Also, application of 5 tons compost plus $120 \mathrm{~kg} \mathrm{~N} /$ ha gave the highest productivity of rice cultivar Sakha 105 Kafrelsheikh.

Keywords: Rice, yield, planting method, traditional transplanting, beds transplanting, compost, $\mathrm{N}$ fertilizer.
\end{abstract}




\section{INTRODUCTION}

Rice crop is an important strategic crop in Egypt and the world; it is a main stable food for the majority of the population and has become a cash export crop. So, increasing its production is a national target in Egypt, the rice is adapted to growing under flooded conditions such as the Egyptian conditions. Rice is one of the major water consuming crops and as the flooding method in rice for irrigation by the farmers and with what Egypt was facing trying to reduce the share of the Nile water must therefore look at new rice planting methods led to irrigation water saving without significant reduction in yield. A major goal is the improving of agronomic practices, especially nutrition, planting methods and water management to finding ways for saving more irrigation water and determine the best rate of organic and mineral fertilizers to obtain a higher yield of rice. Islam and Ghani (1990) recorded that the highest grain yield and water use efficiency were observed with the 3-row design, the difference in yield between normal flooding and 3row irrigation in between beds was not significant. About $40-60 \%$ irrigation water could be saved by using the 3-row between beds irrigation method as compared with the conventional flooding method of irrigation. Atta( 2005) found that applying the innovative planting method for cv. Sakha 104 obtained the highest grain yield per hectare as compared with traditional planting (3.4\% increment). Atta et al. (2006) showed that planting in strips of beds $80 \mathrm{~cm}$ wide resulted the highest values of grain yield followed by the traditional planting. jagroop et al. (2007) revealed grain yield of rice transplanted in beds and on beds was at par with recommended planting method of flat planting, the furrow and bed planting saved $119.5 \mathrm{~cm}(39.0 \%)$ irrigation water from puddling to harvest and 44.2 to $50.0 \%$ more water. Meleha et al. (2008) reported that planting in bottom of beds increased grain yield compared with traditional planting method. Maha (2009) reported that planting in bottom of beds saved 35.34 \& $33.9 \%$ of irrigation water compared with traditional planting method over the two seasons respectively. Chunlin (2010) evaluated the furrow irrigation (FI) system to improve water use efficiency (WUE) and production of direct sowing rice in Southern China as compared to the conventional irrigation $(\mathrm{Cl})$ system (continuous flooding irrigation), the furrow irrigation (FI) system reduced water use by $3130 \mathrm{m3}$, or $48.1 \%$, and increased grain production by $13.9 \%$ for an early cultivar and For a late cultivar, the $\mathrm{FI}$ system reduced water use by $40.6 \%$, and an increase of grain production by $12.1 \%$.

The nitrogen element is one of the important factors to obtain the highest grain yield of rice which is an essential for improving rice growth and grain yield. Mineral or organic fertilizers can be supplied the nitrogen to plant. Several studies reported rice yield and its attributes were significantly affected by nitrogen application(Sahoo et al., 1990 and Manzoor et al.,2006 ).

Sharief et al. (2006) reported that increasing nitrogen fertilizer up to 60 $\mathrm{kg} \mathrm{N} / \mathrm{fed}$ recorded the highest grain yield and yield components in both seasons. Nasef et al. (2009) recommended that application of compost in combination with mineral nitrogen fertilizer led to increase significantly grain yield and weight of 1000 grains. 
So the present investigation was conducted to study the possibility of rice production under two planting methods and three treatments of mineral and organic nitrogen fertilizers as well as their interaction on growth and yield of rice in north Delta, region.

\section{MATERIALS AND METHODS}

Two field experiments were conducted at the Experimental Farm of Water Requirements Research Station, Kafr EL-Sheikh Governorate, North Delta, Water Management Research Institute, National Water Research Centre, Egypt, during summer seasons of 2010 and 2011. The experimental design was split plot with four replicates, where the two methods of planting were distributed in the main plots, while the mineral and organic nitrogen sources were allocated in the sub plots. The two planting methods were traditional transplanting and transplanting in bottom of bed $(30 \mathrm{~cm})$. Bed raised was $(20 \mathrm{~cm})$ high $\times 35 \mathrm{~cm}$ wide the distance between the mid of furrow to mid another was $60 \mathrm{~cm}$. Ditches of $2.5 \mathrm{~m}$ in width were isolated between the plots to prevent the lateral water movement.

Mineral and organic nitrogen fertilizer were $160 \mathrm{~kg}$ mineral N/ha, $120 \mathrm{~kg}$ mineral $\mathrm{N}+5$ tons compost/ha and $80 \mathrm{~kg}$ mineral $\mathrm{N}+5$ tons compost $/ \mathrm{ha}$. The mineral nitrogen fertilizer was applied in the form of urea $(46.6 \% \mathrm{~N})$ in two doses; the first dose (2/3) at transplanting and after complete soil preparation and the second dose was at panicle initiation stage, while the organic source fertilizer (compost) which was incorporated in dry soil after complete soil preparation During soil preparation, the rate of $230 \mathrm{~kg} / \mathrm{ha}$ calcium super phosphate $\left(15.5 \% \mathrm{P}_{2} \mathrm{O}_{5}\right)$ was added. Compost was made from rice straw according to Abdulla (2007). Before soil preparation the samples of soils were collected from $(0-30 \mathrm{~cm}$ depth) the experimental sites in both seasons to determine soil analysis. Soil and compost samples were physically analyzed, according to Piper (1950) and chemically analyzed, according to Black et al. (1965). Soil and compost analysis are presented in Table 1.

Table (1): Analysis of the experimental soil and compost.

\begin{tabular}{|c|c|c|c|c|c|c|c|c|c|}
\hline \multirow{3}{*}{ Seasons } & \multicolumn{9}{|c|}{ A: Soil analysis. } \\
\hline & \multirow{2}{*}{$\begin{array}{c}E C_{e} \\
(\mathrm{dS} / \mathrm{m})\end{array}$} & \multirow{2}{*}{ pH } & \multicolumn{3}{|c|}{ Available (ppm) } & \multicolumn{3}{|c|}{$\begin{array}{c}\text { Particle size } \\
\text { distribution (\%) }\end{array}$} & \multirow{2}{*}{$\begin{array}{c}\text { Texture } \\
\text { class }\end{array}$} \\
\hline & & & $\mathbf{N}$ & $\mathbf{P}$ & K & sand & silt & clay & \\
\hline $1 \mathrm{st}$ & 1.98 & 7.90 & 20.36 & 10.38 & 336 & \multirow{2}{*}{20.4} & \multirow{2}{*}{27.3} & \multirow{2}{*}{52.3} & \multirow{2}{*}{ clayey } \\
\hline 2 nd & 1.99 & 8.10 & 19.93 & 10.86 & 346 & & & & \\
\hline \multicolumn{10}{|c|}{ B. Compost analysis } \\
\hline \multirow{3}{*}{$\begin{array}{l}\text { Means of } \\
\text { seasons }\end{array}$} & $\begin{array}{c}\text { EC } \\
(\mathrm{dS} / \mathrm{m})\end{array}$ & $\mathrm{pH}$ & O.C (\%) & $\begin{array}{l}\text { O.M } \\
(\%)\end{array}$ & $\mathrm{C} / \mathrm{N}$ & \multicolumn{4}{|c|}{ Total (\%) } \\
\hline & 1.79 & 7.70 & $10 . .5$ & 18.1 & 11.1 & $\mathbf{N}$ & & & $\mathrm{K}$ \\
\hline & 1.18 & 1.10 & $10 . .5$ & 10.1 & 11.1 & 0.919 & & & 0.578 \\
\hline
\end{tabular}


In the second week of May of the two seasons, rice grains were hand broadcasted in the nursery and twenty seven day-old seedlings were transplanted in hills at $20 \times 20 \mathrm{~cm}$ between hills and rows for traditional planting method and spaced $13 \times 13 \mathrm{~cm}$ in the two rows in bottom of beds method to keep population on $25 \mathrm{hills} / \mathrm{m}^{2}$ for beds. The preceding winter crop was wheat in the two seasons. The other cultural practices were applied as recommended of Rice Research and Training Center.

Dry weight of plants $(\mathrm{g}) / \mathrm{m}^{2}$ and plant height were recorded at heading. At harvest, the following traits were determined: number of panicles/hill, number of grains/panicle, weight of 1000-grains (g), grain yield ( $t /$ ha.), straw yield ( $\mathrm{t} / \mathrm{ha}$ ) and harvest index.

The analysis of variance was carried out according to Gomez and Gomez (1984) for all collected data. Treatment means were compared by Duncan's Multiple Range test according to Duncan (1955). All statistical analysis were performed using analysis of variance technique by means of "MSTATC" computer software package.

Irrigation water applied (IWA):

The amount of irrigation water ( $\mathrm{mm}$ as head) was measured by flow meter in plots of the permanent field by continuously flooded and in bottom of beds.

Field water use efficiency (FWUE):

Field water use efficiency was calculated according to Michael (1978)

$$
\text { FWUE }=\frac{\text { Grain yeild in } \mathrm{tha}^{-1}}{\text { Amount of applied water in } \mathrm{mm}}
$$

\section{RESULTS AND DISCUSSION}

\section{Growth characters:}

Results in Table 2 show the effect of planting method, nitrogen fertilizer treatments and their interaction on dry weight $\left(\mathrm{g} / \mathrm{m}^{2}\right)$ and plant height $(\mathrm{cm})$ in 2010 and 2011 seasons.

Data reveal that planting rice in bottom of beds significantly recorded the highest values of dry weight character as compared with traditional transplanting in both seasons. In the two seasons plant height at heading significantly affected by traditional transplanting methods as ompared with the beds methods. These findings are in agreement with those reported by Meleha et al. (2008). Lu et al. (2000) found that no difference in dry mass production between continuous flooding irrigation treatment and the reduced irrigation treatment. Chunlin (2010) reported that beds irrigation recorded the highest values of leaves and stem dry weight compared with continuous flooding as conventional irrigation especially in the final stage.

None of the interaction had asignificant effect on dry weight and plant height in any of the two seasons under the local conditions of the present investigation (Table 2) 
Data in Table 2 indicate that nitrogen fertilizer treatments had a significant effect on dry weight in the first season and highly significant effect on plant height in both seasons. Data also show that treatment of $120 \mathrm{~kg} \mathrm{~N}$ plus 5 tons compost/ ha gave the highest dry weight without significant differences with treatment of $160 \mathrm{~kg} \mathrm{~N} / \mathrm{ha}$. Also, it is clear from data that the highest mean values of plant height was obtained from application of $120 \mathrm{~kg}$ $\mathrm{N}$ plus 5 tons compost/ha in both seasons. The lowest values of dry weight and plant height were recorded by application of $80 \mathrm{~kg} \mathrm{~N}$ plus 5 tons of compost/ha. These results are in accordance with those obtained by Sharief et al. 2006.

Table 2: Dry weight (g/hill) and Plant height $(\mathrm{cm})$ of rice plants as affected by planting method and nitrogen fertilizer and their interaction during 2010 and 2011 seasons.

\begin{tabular}{|c|c|c|c|c|}
\hline Characters & Dry weig & ht/ hill (g) & Plant he & ight (cm) \\
\hline Treatments & $1^{\text {st }}$ season & $2^{\text {nd }}$ season & $1^{\text {st }}$ season & $2^{\text {nd }}$ season \\
\hline Planting methods: & & & & \\
\hline Traditional & $30.21 \mathrm{~b}$ & $30.32 \mathrm{~b}$ & $105.18 \mathrm{a}$ & 106.32 a \\
\hline Beds & 32.98 a & 32.79 a & $102.93 \mathrm{~b}$ & $104.07 \mathrm{~b}$ \\
\hline F-test & ** & ** & * & ** \\
\hline $\mathrm{N}$ - fertilizer treatments: & & & & \\
\hline 160 kg N/ha. & $31.60 \mathrm{ab}$ & 31.64 & $103.94 \mathrm{~b}$ & $104.99 \mathrm{~b}$ \\
\hline $120 \mathrm{Kg} \mathrm{N}+5$ tons compost/ha & $32.31 \mathrm{a}$ & 32.03 & 106.76 a & $108.3 \mathrm{a}$ \\
\hline $80 \mathrm{Kg} \mathrm{N}+5$ tons compost/ha & $30.86 \mathrm{~b}$ & 30.99 & $101.46 \mathrm{c}$ & $102.29 \mathrm{C}$ \\
\hline F-test & * & ns & ** & ** \\
\hline Interaction: & Ns & Ns & Ns & Ns \\
\hline
\end{tabular}

${ }^{*},{ }^{\star *}$ and Ns indicate $\mathrm{p}<0.05,<0.01$ and not significant, respectively. Means of each treatment followed by the same letter are not significantly different at $5 \%$ level, according to Duncan's multiple range test.

\section{Yield and its components:}

Data in Tables $3 \& 4$ presented yield and its components as affected by planting method, nitrogen fertilizer and their interaction during 2010 and 2011 seasons.

The data in Tables show that planting method had a significant effected on number of panicles/hill , number of grains/panicle, 1000 grain weight, grain yield, straw yield and harvest index in both seasons, except number of grains/panicle and straw yield, which were significantly affected only in the second season.

Its clear from data that planting in bottom of beds recorded the highest and significant values of grains number/panicle in the second season, 1000 grain weight, grain yield, and harvest index in both seasons, while, traditional transplanting gave the highest number of panicle/hill in both seasons and straw yield in the second season only. Theses results are in harmony with those obtained by Islam and Ghani (1990), Atta et al. (2006), Jagroop et al. (2007), Meleha et al (2008) and Chunlin (2010) they reported that beds methods recorded the highest yield and yield components compared with traditional transplanting method. These findings demonstrated that beds method met the water demand for growth and also reduced water loss due to 
evaporation. Beds method also enhanced gas exchange in the soil, which provides a better growth environment for rice production.

Data indicated that all studied traits of yield and yield components significantly affected by nitrogen fertilizer treatments in seasons, Tables 3 and 4.

Table 3: Number of panicles/hill, number of grains/panicle and 1000 grain weight $(\mathrm{g})$ as affected by planting method and nitrogen fertilizer treatments and their interaction during 2010 and 2011 seasons.

\begin{tabular}{|c|c|c|c|c|c|c|}
\hline \multirow{2}{*}{\begin{tabular}{|l} 
Charaters \\
Treatment \\
\end{tabular}} & \multicolumn{2}{|c|}{$\begin{array}{c}\text { No. of } \\
\text { panicles/hill }\end{array}$} & \multicolumn{2}{|c|}{$\begin{array}{c}\text { No. of } \\
\text { grains/panicle }\end{array}$} & \multicolumn{2}{|c|}{$\begin{array}{c}1000 \text { grain weight } \\
(\mathrm{g})\end{array}$} \\
\hline & $\begin{array}{c}1^{\text {st }} \\
\text { season }\end{array}$ & $\begin{array}{c}2^{\text {nd }} \\
\text { season }\end{array}$ & $\begin{array}{c}1^{\text {st }} \\
\text { season }\end{array}$ & $\begin{array}{c}2^{\text {nd }} \\
\text { season }\end{array}$ & $\begin{array}{c}1^{\text {st }} \\
\text { season }\end{array}$ & $\begin{array}{c}2^{\text {nd }} \\
\text { season }\end{array}$ \\
\hline \multicolumn{7}{|l|}{ Planting methods: } \\
\hline Traditional & $23.5 \mathrm{a}$ & $22.90 \mathrm{a}$ & 100.28 & $100.42 \mathrm{~b}$ & $23.41 \mathrm{~b}$ & $23.29 \mathrm{~b}$ \\
\hline Beds & $21.80 \mathrm{~b}$ & $22.08 \mathrm{~b}$ & 99.87 & $101.51 \mathrm{a}$ & $24.19 \mathrm{a}$ & $24.51 \mathrm{a}$ \\
\hline F-test & * & * & Ns & ** & ** & * \\
\hline \multicolumn{7}{|l|}{$\mathrm{N}$ - fertilizer treatments } \\
\hline $160 \mathrm{~kg} \mathrm{~N} / \mathrm{ha}$. & $22.33 \mathrm{~b}$ & $22.66 \mathrm{~b}$ & $99.48 \mathrm{~b}$ & $100.56 \mathrm{~b}$ & $23.84 \mathrm{a}$ & $23.93 \mathrm{~b}$ \\
\hline $\begin{array}{l}120 \mathrm{~kg} \mathrm{~N}+5 \text { tons compost/ } \\
\text { ha }\end{array}$ & $23.59 \mathrm{a}$ & $23.44 \mathrm{a}$ & $102.43 \mathrm{a}$ & $102.99 \mathrm{a}$ & $24.38 a$ & $24.46 \mathrm{a}$ \\
\hline $\begin{array}{l}80 \mathrm{~g} \mathrm{~N}+5 \text { tons compost / } \\
\text { ha }\end{array}$ & $21.36 \mathrm{c}$ & $21.36 \mathrm{c}$ & $98.31 \mathrm{c}$ & $99.34 \mathrm{c}$ & $23.18 b$ & $23.31 \mathrm{c}$ \\
\hline F-test & ** & $* *$ & ** & $\star * *$ & ** & ** \\
\hline Interaction: & Ns & Ns & Ns & Ns & Ns & Ns \\
\hline
\end{tabular}

${ }^{*},{ }^{\star \star}$ and Ns indicate $\mathrm{p}<0.05,<0.01$ and not significant, respectively. Means of each treatment followed by the same letter are not significantly different at $5 \%$ level, according to Duncan's multiple range tests.

Table 4: Grain and straw yields (t/ha) and harvest index as affected by planting method and nitrogen fertilizer treatments and their interaction during 2010 and 2011 seasons.

\begin{tabular}{|c|c|c|c|c|c|c|}
\hline Characters & \multicolumn{2}{|c|}{ Grain Yield (t/ha) } & \multicolumn{2}{|c|}{ Straw Yield (t/ha) } & \multicolumn{2}{|c|}{ Harvest index (\%) } \\
\hline Treatment & $\begin{array}{c}1^{\text {st }} \\
\text { season }\end{array}$ & $\begin{array}{c}2^{\text {nd }} \\
\text { season }\end{array}$ & $\begin{array}{c}1^{\text {st }} \\
\text { season }\end{array}$ & $\begin{array}{c}2^{\text {nd }} \\
\text { season }\end{array}$ & $\begin{array}{c}1^{\text {st }} \\
\text { season }\end{array}$ & $\begin{array}{c}2^{\text {nd }} \\
\text { season }\end{array}$ \\
\hline \multicolumn{7}{|l|}{ Planting methods: } \\
\hline Traditional & $10.64 \mathrm{~b}$ & $10.76 \mathrm{~b}$ & 14.85 & $15.21 \mathrm{a}$ & $0.42 \mathrm{~b}$ & $0.42 \mathrm{~b}$ \\
\hline Beds & $12.09 \mathrm{a}$ & $12.14 \mathrm{a}$ & 14.07 & $13.85 \mathrm{~b}$ & $0.46 \mathrm{a}$ & $0.48 \mathrm{a}$ \\
\hline F-test & ** & ** & Ns & * & ** & ** \\
\hline \multicolumn{7}{|l|}{$\mathrm{N}$ - fertilizer treatments : } \\
\hline $160 \mathrm{~kg} \mathrm{~N} / \mathrm{ha}$. & $11.42 \mathrm{~b}$ & $11.38 \mathrm{a}$ & $13.83 \mathrm{~b}$ & $14.35 b$ & $0.45 \mathrm{a}$ & $0.44 \mathrm{ab}$ \\
\hline $\begin{array}{l}120 \mathrm{~kg} \mathrm{~N}+5 \text { ton } \\
\text { compost/ ha compost }\end{array}$ & $12.14 \mathrm{a}$ & $12.19 \mathrm{a}$ & $15.40 \mathrm{a}$ & $15.04 \mathrm{a}$ & $0.44 \mathrm{a}$ & $0.45 \mathrm{a}$ \\
\hline $\begin{array}{l}80 \mathrm{~kg} \mathrm{~N}+5 \text { ton compost } \\
\mathrm{ha}\end{array}$ & $10.52 \mathrm{c}$ & $10.81 \mathrm{c}$ & $14.14 \mathrm{~b}$ & $14.16 \mathrm{~b}$ & $0.43 \mathrm{~b}$ & $0.43 \mathrm{~b}$ \\
\hline F-test & ** & ** & ** & * & ** & * \\
\hline Interaction & Ns & Ns & Ns & Ns & Ns & Ns \\
\hline
\end{tabular}

${ }^{*},{ }^{\star *}$ and Ns indicate $\mathrm{p}<0.05,<0.01$ and not significant, respectively. Means of each treatment followed by the same letter are not significantly different at $5 \%$ level, according to Duncan's multiple range tests. 
Data show that application of $120 \mathrm{~kg} \mathrm{~N}$ plus 5 tons compost/ha recorded the highest and significant values of number of panicles /hill, number of grains /panicle, 1000 grain weight, grain yield, straw yield and harvest index as compared with $160 \mathrm{~kg} \mathrm{~N} / \mathrm{ha}$, which did not significantly differed with application of $120 \mathrm{~kg} \mathrm{~N} /$ ha plus 5 tons compost $/$ ha in 1000 grain weight.

There are no significant differences between applications of $160 \mathrm{~kg}$ $\mathrm{N} /$ ha as mineral source and $120 \mathrm{~kg} \mathrm{~N}+5$ tons compost/ha in 1000 grain weight in the first season, grain yield in the second season and harvest index in both seasons. While the lowest values of yield and its components were obtained by application of $80 \mathrm{~kg} \mathrm{~N}+5$ tons compost/ha in both seasons. Similar results were reported by Nasef et al. (2009).

Yield and yield components were not affected in any of the two seasons by the interaction between the two factors involved in this study indicating, thereby, that each factor affected this characters independently

\section{Water relations: \\ Total applied water:}

Data of total water applied are presented in Table (5). The obtained data clearly show that the applied total applied water applied were 3584.28 \& 2441.88 and $3586.66 \& 2446.64 \mathrm{~mm}$ under traditional and beds methods in the first and second seasons, respectively. It was evident that traditional method received the highest amount of irrigation water compared with beds method. The water saving were 1142.4 and $1140.02 \mathrm{~mm} \mathrm{(4798.1}$ and 4788.1 $\mathrm{m}^{3} / \mathrm{ha}$ equivalent 2016 and $2011.8 \mathrm{~m} 3 / \mathrm{fed}$.) in the first and second seasons, respectively. These results are in accordance with those obtained by Atta (2005), Atta et al. (2006), Meleha et al. (2008) and Maha (2009).

Table (5): Total of applied water in $\mathrm{mm}$ as related to planting method during 2010 and 2011 seasons.

\begin{tabular}{|l|c|c|c|c|}
\hline \multirow{2}{*}{ rrait } & \multicolumn{3}{|c|}{$\mathbf{1}^{\text {st }}$ season } & \multicolumn{2}{c|}{$\mathbf{2}^{\text {nd }}$ season } \\
\cline { 2 - 5 } & Traditional & Beds & Traditional & Beds \\
\hline Land preparation of the & & & & \\
nursery & 57.12 & 57.12 & 59.5 & 57.12 \\
\hline Seedling raising (25 days) & 83.3 & 83.3 & 83.3 & 83.3 \\
\hline $\begin{array}{l}\text { Preparation of the permanent } \\
\text { field }\end{array}$ & 537.88 & - & 540.26 & - \\
\hline Planting & - & 385.56 & - & 387.94 \\
\hline June & 811.58 & 514.08 & 811.58 & 518.84 \\
\hline July & 1235.22 & 785.4 & 1237.6 & 785.4 \\
\hline August & 728.28 & 521.22 & 725.9 & 518.84 \\
\hline September & 130.9 & 95.2 & 128.52 & 95.2 \\
\hline Total water (mm)/ ha & 3584.28 & 2441.88 & 3586.66 & 2446.64 \\
\hline total (m $\mathbf{m}^{\mathbf{3}}$ ha) & 15053.98 & 10255.9 & 15063.97 & 10275.89 \\
\hline
\end{tabular}


Field water use efficiency (FWUE):

One of the most extensively used terms to evaluate the performance of irrigation system is water efficiency .Data presented in Table 6 reveal that the field water use efficiency as affected by treatments were 0.00296 \& $0.00299 \mathrm{t} / \mathrm{mm}$ (ton grains $/ \mathrm{mm}$ f water applied) and $0.00495 \& 0.00496 \mathrm{t} / \mathrm{mm}$ for traditional and beds methods during 2010 and 2011 seasons, respectively. It could be concluded that the furrow method recorded the highest value. Similar results were obtained by Atta (2005), Atta et al. (2006), Meleha et al. (2008) and Maha (2009). Chunlin (2010) reported that the beds irrigation system improved water use efficiency (WUE) as compared to the conventional irrigation system (continuous flooding irrigation) and resulted in reduced the water using.

Table (6): Field water use efficiency $\left(\mathrm{kg} / \mathrm{m}^{3}\right)$ as affected by different planting methods during 2010 and 2011 seasons.

\begin{tabular}{|l|c|c|c|c|c|c|}
\hline \multicolumn{1}{|c|}{ Treatment } & \multicolumn{2}{c|}{ Grain yield(t/ha) } & \multicolumn{2}{c|}{$\begin{array}{c}\text { Total applied water } \\
\text { (mm/ht) }\end{array}$} & \multicolumn{2}{c|}{$\begin{array}{c}\text { Field water use } \\
\text { efficiency(t/mm) }\end{array}$} \\
\hline Planting Method: & $\mathbf{2 0 1 0}$ & $\mathbf{2 0 1 1}$ & $\mathbf{2 0 1 0}$ & $\mathbf{2 0 1 1}$ & $\mathbf{2 0 1 0}$ & $\mathbf{2 0 1 1}$ \\
\hline Traditional & 10.64 & 10.76 & 3584 & 3587 & 0.00296 & 0.00299 \\
\hline Beds & 12.09 & 12.14 & 2442 & 2447 & 0,00495 & 0,00496 \\
\hline
\end{tabular}

\section{REFERENCES}

Abdulla, H. (2007). Enhancement of Rice Straw Composting by Lignocellulolytic Actinomycete. Strains. International Journal of Agriculture \& biology, 9 (1): $106-109$.

Atta, Y. I. M. (2005). Strip transplanting of rice, anew method for increasing, water use efficiency under splitting of nitrogen fertilizer. Egypt, J. of Appl. Sci., 20 (10B): 501- 511.

Atta, Y. I. M.; M.E. Meleha; A. Tallet and U.M. Gawish (2006). Improving water productivity in rice cultivation with high potential for water saving. The $3^{\text {rd }}$ Arab world Region Conference, Cairo, 4-11 December, 2006.

Black, C.; D. Evans; L. Ensminger and F. Clark (1965). Methods of soil analysis (Chemical and Microbiological) properties, Part (2). Amer. Soc., Agronomy, Inc. Pub., Madison, Wisconsin, U.S.A.

Chunlin, H. (2010). Effects of Furrow Irrigation on the Growth, Production, and Water Use Efficiency of Direct Sowing Rice. The Scientific World Journal, 10: 1438-1497. (C.F Computer search).

Duncan , B.D. (1995). Multiple Range and Multiple F. Test. Biometrics.11: 142.

Gomez, K. and A. Gomez (1984). Statistical Procedures of Agricultural Research. John Wiley and Sons. Inc., New York, U.S.A.

Islam, M.J. and M.A Ghani, (1990). Impact of furrow irrigation on rice production. Bangladesh Rice Journal, 1(1): 32-36.

Jagroop K.; R. K. Mahey; K. K. Vashist and S. S. Mahal (2007). Growth and productivity of rice (Oryza sativa L.) and water expense efficiency as influenced by different planting techniques. Environment and Ecology, 25(1): 235-238 
Lu, j.; T. Ookawa and T. Hirasawa (2000). The effects of irrigation regimes on the water use, dry matter production and physiological responses of paddy rice. Plant Soil, 223: 209-218.

Maha, A. A. Elbiealy (2009). Irrigation water management of rice crop PhD Thesis, Fac. Agric. Mansoura Univ.

Manzoor, Z.; R.I.Ali, T. H. Awan, N. khaled and Mushtaq Ahmad (2006). Appropriate time of nitrogen Application to fine rice, oryza sativa. J. Agric., Res., 44(4): 261-267

Meleha, M.E.; A.Z. El-Bably; A.A. Abd Allah and W.M. El-Khoby (2008). Producing more rice with less water by inducing planting methods in North Delta, Egypt. J. Agric. Sci., Mansoura Univ., 33: 805 -813.

Michael, A.M.(1978). Irrigation theory and practices. Vikas publishing House puttd New Delhi, Bombay.

Nasef, M.A.; Kh. A. Shaban and Amal F.Abd El-Hamid (2009). Effect of compost tea and bio-fertilizer application on some chemical soil properties and rice productivity under saline soil conditions. J. Agric .Sci., Mansoura Univ., 34 (4): 2609 -2623.

Piper, C. (1950).Soil and plant analysis Inc. Soc., Pub. Inc., New York, U.S.A.

Sahoo, N. C.; B. K. Mishra and J. P. Mohanty (1990). Response of aged seedlings of transplanted rice to split application of nitrogen. Orissa $\mathrm{J}$. Agric., Res., 3(10):13-17

Sharief, A. E.; S.E. El-Kalla; A.T.El-kassaby; M.H. Ghonema and G.M. Abdo (2006). Effect of Bio chemical fertilization and times of nutrients foliar application on growth, yield and yield components of rice. J. Agronomy, 5 (2): 212-219.

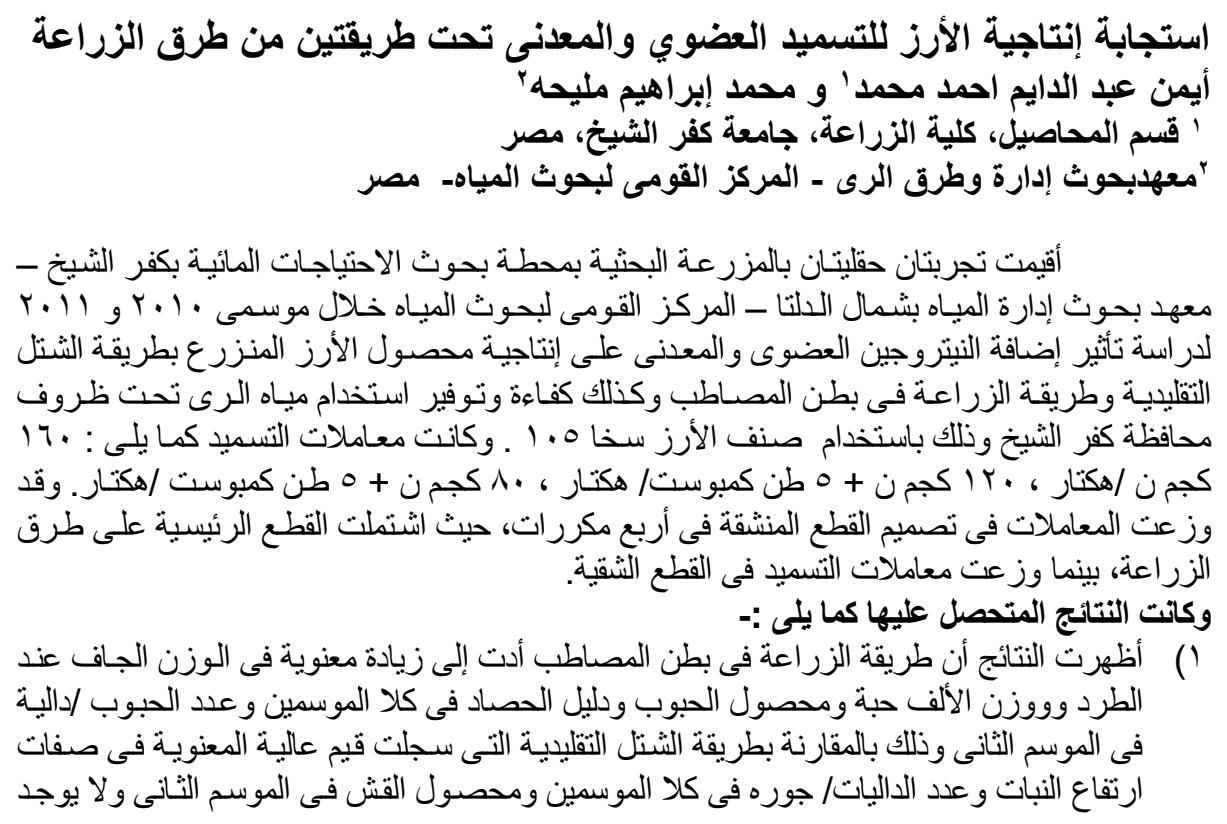




\section{Ahmed, A. A. and M. E. Meleha}

ختنافا معنويا بين كلتا الطريقتين فى تأثئير هما على صفات عدد الحبوب/ دالية ومحصول القش فى

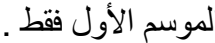

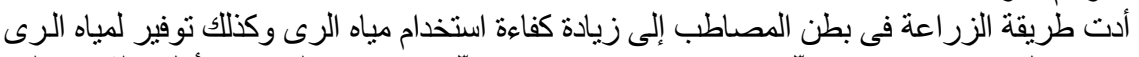

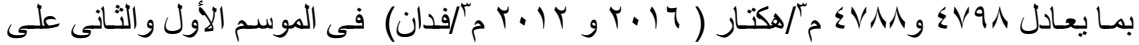
التو الى مقارنة بطريقة الثنتل التقليدية.

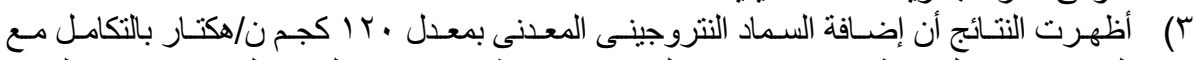

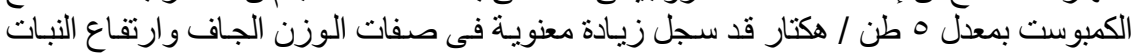

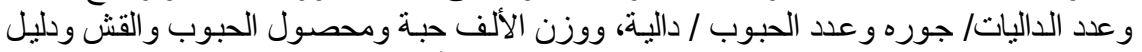

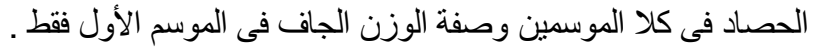

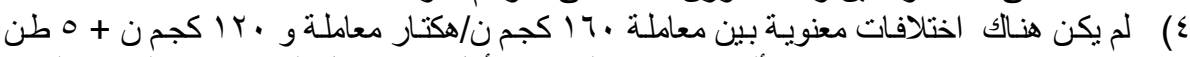

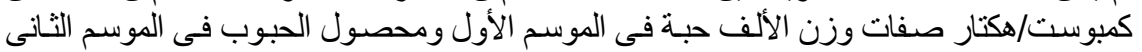
ودليل الحصاد فى كلا الموسمين.

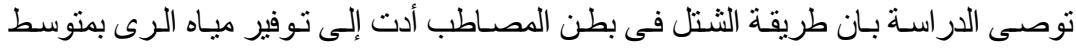

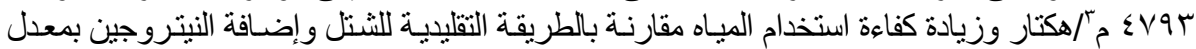

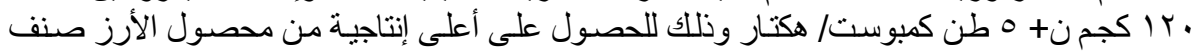
سخا م. 1 تحت ظروف محافظة كفر الثيخ.

كلية الزراعة - جامعة المنصورة كلية الزراعة - جامعة كفر الشيخ

$$
\text { قام بتحكيم البحث }
$$

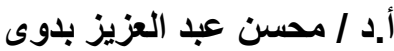
أ.د / أد / عبد الواحد عبد الحميز بدوي السيد 